IZA DP No. 470

\title{
Does Globalisation Increase Child Labour?
}

\author{
Alessandro Cigno \\ Furio C. Rosati \\ Lorenzo Guarcello
}

April 2002 


\title{
Does Globalisation Increase Child Labour?
}

\author{
Alessandro Cigno \\ University of Florence, CESifo, CHILD and IZA, Bonn \\ Furio C. Rosati \\ University of Sassari, University of Rome "Tor Vergata" and UNICEF \\ Lorenzo Guarcello \\ UNICEF
}

\author{
Discussion Paper No. 470 \\ April 2002
}

\author{
IZA \\ P.O. Box 7240 \\ D-53072 Bonn \\ Germany \\ Tel.: +49-228-3894-0 \\ Fax: +49-228-3894-210 \\ Email: iza@iza.org
}

This Discussion Paper is issued within the framework of IZA's research area Internationalization of Labor Markets. Any opinions expressed here are those of the author(s) and not those of the institute. Research disseminated by IZA may include views on policy, but the institute itself takes no institutional policy positions.

The Institute for the Study of Labor (IZA) in Bonn is a local and virtual international research center and a place of communication between science, politics and business. IZA is an independent, nonprofit limited liability company (Gesellschaft mit beschränkter Haftung) supported by the Deutsche Post AG. The center is associated with the University of Bonn and offers a stimulating research environment through its research networks, research support, and visitors and doctoral programs. IZA engages in (i) original and internationally competitive research in all fields of labor economics, (ii) development of policy concepts, and (iii) dissemination of research results and concepts to the interested public. The current research program deals with (1) mobility and flexibility of labor, (2) internationalization of labor markets, (3) welfare state and labor markets, (4) labor markets in transition countries, (5) the future of labor, (6) evaluation of labor market policies and projects and (7) general labor economics.

IZA Discussion Papers often represent preliminary work and are circulated to encourage discussion. Citation of such a paper should account for its provisional character. A revised version may be available on the IZA website (www.iza.org) or directly from the author. 
IZA Discussion Paper No. 470

April 2002

\section{ABSTRACT}

\section{Does Globalisation Increase Child Labour?}

There is no empirical evidence that trade exposure per se increases child labour. As trade theory and household economics lead us to expect, the cross-country evidence seems to indicate that trade reduces or, at worst, has no significant effect on child labour. Consistently with the theory, a comparatively well educated labour force, and active social policies, appear to be conducive to a reduction in child labour. For countries with a largely uneducated workforce, the problem is not so much globalisation, as being allowed to take part in it.

JEL Classification: D13, F12, I20, J13, J24, O15

Keywords: child labour, globalisation, education, health, skill premium, trade

Alessandro Cigno

Università di Firenze

Dipartimento di Studi sullo Stato

Via S. Caterina d'Alessandria 3

I-50129 Firenze

Italy

Tel.: +39 055-4622922

Fax: +39 055-472102

Email: cigno@unifi.it 


\section{Introduction}

Globalisation, the process by which an increasing share of world production is traded internationally, and the productive systems of different countries become increasingly integrated, is credited with many merits and held responsible for many evils. The present paper attempts to answer the following question: given that international trade has major allocative and distributive implications, are children likely to be among the losers? More specifically, given that child labour appears to be on the increase worldwide, could this be a consequence of globalisation?

The current wave of globalisation started soon after the end of the second world war, but got in its stride in the $1980 \mathrm{~s}$, as rapid progress in information and transport technology compounded the effects of trade liberalisation (Krugman, 1995). To try and understand the consequences of globalisation it thus seems reasonable to look at what has happened over the last couple of decades. Much of the existing literature on the subject is concerned with the consequences of globalisation for wages and employment in the developed world (Wood, 1998). Since our concern is child labour, and child labour is concentrated mainly in the developing world, ${ }^{2}$ we shall focus on developing countries.

A useful source of cross-country information on child labour and international trade are the World Bank's Development Indicators. Another valuable source of information on trade openness is Sachs and Warner (1995), which classifies a country as "open" if free from a number of obstacles to trade, from non-tariff barriers to state monopoly on major exports. Combining these two sources of information, we assembled a set of relevant data on all developing countries for the relevant years available, namely 1980, 1990, 1995 and 1998.

The measure of child labour that figures in the Development Indicators is the participation rate of persons aged 10 to 14 . That is an important indicator of early involvement in work activities, but presents two lacunae. The first is that, by excluding children younger than 10, it leaves out a large, arguably the most worrisome, part of the phenomenon in question. A substantial number of children in that age group is working either part or full time. According to the 1999 National

\footnotetext{
${ }^{2}$ Though not on a comparable scale, child labour is becoming a problem also in developed countries. There, however, it is largely connected with clandestine immigration. One way or another, the main source of child workers is thus the developing world.
} 
Council of Applied Economic Research survey of rural Indian households, for example, around 10 percent of children aged 6 to 10 were reported by their parents as working in one way or another. ${ }^{3}$ The second lacuna is that this measure of child labour does not include children working within the household, and does not account for children engaged in unofficial, especially if illegal, work activities. We know from other sources, however, that children are extensively engaged in domestic activities, and that many children reportedly doing nothing could be actually working. For example, in the already mentioned Indian survey, the place where children are most commonly reported to be working is the household. In the same survey, as much as a quarter of children between the ages of 6 and 14 is reported as neither working nor attending school, but there are reasons to suspect that a sizeable proportion of them works (Cigno and Rosati, 2002).

As an alternative to this measure of child labour, we shall use also the primary school non-attendance rate (the complement to unity of the primary school net enrolment rate reported in the Development Indicators). The shortcoming of this alternative measure is that a child not attending school is not necessarily working. On the other hand, however, children not reporting for school are more difficult to monitor, and thus more at risk of exposure to the worst forms of abuse - from hazardous or very hard work, to soldiering and prostitution - than children regularly available for inspection by the school authorities (Cigno, Rosati and Tzannatos, 2002). Therefore, the non-attendance rate is not only a correlate of child labour at very young ages, but also a valuable danger signal. The 10-14 labour participation rate and the primary school non-attendance rate are positively correlated with each other across countries and years of observation, but the coefficient of correlation is much less than unity.

\footnotetext{
${ }^{3}$ Detailed information for about 40 countries can be found at www.ucw-project.org.
} 
Figure 1.Correlation between Child Labour and Trade

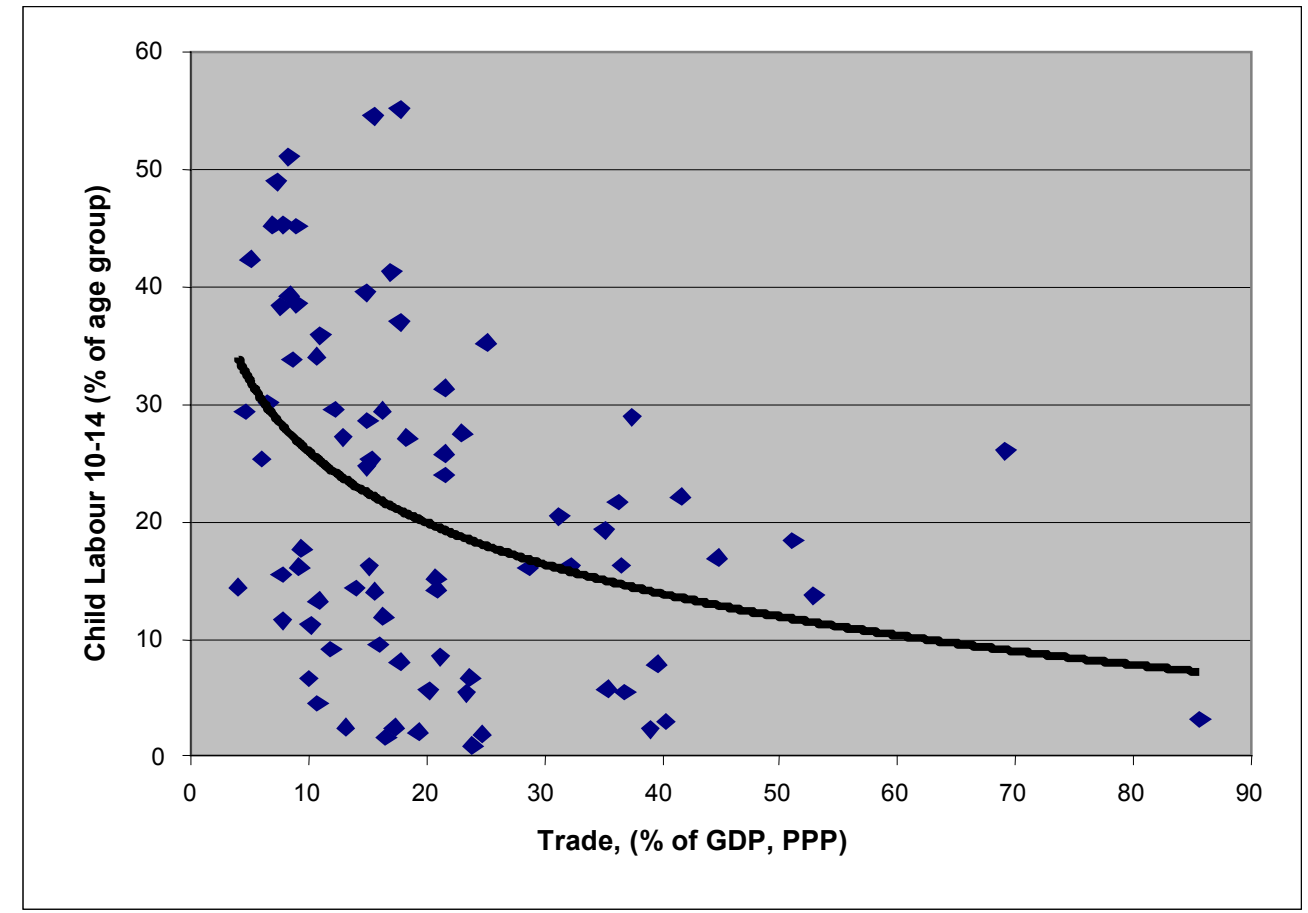

Figures 1 and 2 show that both measures of child labour are negatively correlated with trade openness as conventionally measured (imports plus exports, divided by GDP). The interpolating line is shown just as a guide to the eye, and should not be interpreted as a causal relationship. It is interesting to note, however, that the dispersion around this interpolating line tends to decrease as trade increases. In other words, countries with little international exposure differ more widely with regard to child labour than countries well integrated in the global economy. Those with trade up to 20 percent of GDP, for example, have labour participation rates for 10-14 year olds ranging from little over zero to more than 55 percent, and primary school non-attendance rates ranging between zero and 80 percent. By contrast, in countries with trade equal to more than 40 percent of GDP, both measures of child labour range between little over zero and little over a quarter of the relevant age group. 
Figure 2. Correlation between Primary School Non-Attendance rate and Trade



The finding that trade makes countries more alike is hardly surprising. The finding that trading countries tend to have less child labour than autarchic ones is less obvious. Let us see what economic theory has to say on the matter.

\section{Household decisions}

The first thing to be kept in mind is that children do not normally choose to work. Most have that decision taken for them, mainly by their parents. Even in the case of a child who was expelled or run away from home, the reasons for his or her predicament can be traced back to parental actions. ${ }^{4}$ The second is that the great majority of working children is employed in the family business, most often a farm, or in the household itself (looking after younger siblings, and generally substituting for adult members in the performance of domestic chores). ${ }^{5}$ Therefore, the first piece of economic theory to be looked at is household economics, which describes the

\footnotetext{
${ }^{4}$ The only exception are children who lost their family of origin because of some catastrophic event (war, natural disaster), and those who were abducted; see Cigno, Rosati and Tzannatos (2002).

${ }^{5}$ See Cigno, Rosati and Tzannatos (2001).
} 
household as a "small open economy" immersed in a wider market economy (Cigno, 1991).

Much of this literature is based on the assumption that a parent, or parents jointly, act as a kind of benevolent dictator. Except in extreme cases, ${ }^{6}$ however, many of the theoretical predictions are qualitatively the same whether one assumes that parents are altruistically inclined towards their offspring (Becker, 1981) or ultimately self-interested (Cigno 1993; Rosati 1996). So long as parents care about their own as well as their children's consumption, the decision whether to send a child to work or to school does in fact depend on essentially three things: the cost (including the opportunity-cost) of education, the expected return to education, an the extent to which parents are able to finance educational investments. ${ }^{7}$

Three types of outcome are possible (Cigno and Rosati, 2002). If the marginal cost of education (say, the cost of increasing the child's future earning ability by one dollar) is everywhere higher than the maximum that parents are willing to pay for it, we have a corner solution with the child working full time. Another corner solution arises if the marginal cost of education for a child studying full time is lower than the minimum at which parents are willing to forgo their children's earnings altogether. If that is the case, the child studies full time. If the marginal cost of education falls between those two limits, we have an interior solution, with the child working and attending school at the same time. How much parents are willing to pay, at the margin, for a child's education depends not only on preferences, but also on the expected return to education (Rosenzweig, 1995). If parental preferences are nonaltruistic, it will depend also on how much of that return can be appropriated by parents (Cigno, 1993; Rosati, 1996).

An important role in determining whether a child will work or go to school is played by the capital market. Suppose that a child's future earnings could be substantially enhanced by education. Were it possible to borrow against those expected future earnings, parents could use the amount borrowed to finance the child's education and current consumption. If that is not possible, however, the child's education will have to be financed out of the household's current earnings and assets.

\footnotetext{
${ }^{6}$ Basu and Van (1998), for example, assume that parents will make their children work only if the alternative is starvation.

${ }^{7}$ See Cigno and Rosati (2002), Grootaert and Kanbur (1995), Rosati (2000).
} 


\subsection{The effects of wage rate changes}

If the time-allocation problem has an interior solution, wage rate changes have substitution-effects. In the absence of a liquidity constraint, any wage increase will have also an income-effect on the demand for education, positive if we assume that human capital (the child's future skill level) is a normal good, ${ }^{8}$. In the presence of a binding liquidity constraint, however, there can be income-effects only if the change concerns current wage rates.

Consider first the case of an increase in the wage rate for uneducated workers, holding other wage rates constant. As the expected return to education falls, there is a substitution away from education. There is, on the other hand, a positive incomeeffect, stronger in households where the parents are themselves uneducated.. The net effect on the supply of child labour is thus ambiguous.

The picture is somewhat different if there is an increase in the wage rate for educated workers. As the expected return to education increases, the substitution is now away from child labour. In households where the adults are educated, the substitution-effect will be reinforced by an income-effect. Where the adults are uneducated, there will be an income-effect only if the liquidity constraint is not binding. The supply of child labour will fall anyway.

If the household is initially at a corner, with the child either working full time or studying full time, there will obviously be no substitution effects. But a large enough increase in the wage rate for educated workers will (and an increase in the wage rate for uneducated workers may) reduce child labour.

\subsection{The effects of policy}

We have seen that capital market imperfection establishes a link between child labour participation, and current income (Balland and Robinson, 2000, Rosati 1999). Whether this household-level link will translate into an aggregate-level relationship between child labour and per-capita income depends on income distribution and educational policies. Other things being equal, the more successful a government is in re-distributing income through the tax system, or in directly subsidising education, the lower the child labour rate associated with any given level of per-capita income.

\footnotetext{
${ }^{8}$ Either in the sense that higher future earnings translate into higher future consumption for the child (Becker, 1981), and that this is a normal good, or in the sense that they translate into higher future consumption for the parents themselves (Cigno, 1993), and that this is a normal good.
} 
Parents determine the household's supply of child labour (to itself or to the market) not only by disposing of the time of existing children, but also by determining how many children there are. Parental actions, such as frequency of intercourse and use of contraception, do in fact condition the probability distribution of a birth. Once a child is born, parental actions, such as expenditure for the child's nutrition and health care, ${ }^{9}$ condition the child's probability of survival to an age where he or she can be made to work (Cigno, 1998). This last aspect is particularly relevant for developing countries, where infant mortality is counted per hundred rather than thousand live births.

Of course, the probability that a child will survive to school age depends not only on parental actions, but also on external causes, such as climate and genetic factors. It depends also on government expenditure for health and sanitation. The higher this expenditure, the higher, other things being equal, the probability that a child will survive to school age, and later to adulthood; the higher, consequently, the return to investing in a child's education. Other things, however, are not equal.

If public health expenditure is a complement for private (parental) expenditure on a child's health and nutrition, in the sense that the former raises the expected marginal utility of the latter, then an increase in public expenditure will induce parents to raise their contribution. If the two are substitutes, in the sense that public expenditure lowers the expected marginal utility of private expenditure, the effect may be the opposite. May, not will, because there is a income and a substitution effect. The latter is definitely negative, but the former is positive because parents can now procure the same number of surviving children at lower cost, and it is thus as if they had become richer (Cigno, 1998). In the first case, public expenditure crowds in private expenditure, in the second it crowds it out.

Even if there is crowding out, however, it is unlikely that this will be total. We may thus expect an increase in public expenditure for health or sanitation to reduce the incidence of child labour by inducing parents to switch from a high-fertility, lowsurvival, low-education to a low-fertility, high-survival, high-education strategy. ${ }^{10}$ Micro-econometric evidence of interactions between public health provision and

\footnotetext{
${ }^{9}$ Expenditures on nutrition and health reduce not only mortality, but also morbidity. Since the two are positively correlated, everything we say about the effects of parental and government actions on the probability premature death applies also to the probability of illness (and thus to a child's future ability to work or study with profit).
} 
educational policies is reported in Cigno and Rosati (2002) and Rosenzweig and Wolpin (1982).

\section{The effect of trade}

The second relevant piece of economics is trade theory. We know from David Ricardo that a country enjoys higher welfare if, instead of directly producing all the goods its members wish to consume, it specializes in the production of goods it can produce at comparatively lower cost, and exchanges the surplus for those it does not produce in sufficient quantity. The same may be said about households, and about individuals within households Cigno (1991, 2001).

Since the cost of a good depends on the prices of the factors used for its production, and the prices of traded factors are the same everywhere, differences in the relative costs of traded goods reflect differences in the relative prices of nontradeables used as factors of production. In turn, the relative prices of these immobile factors reflect differences in endowments. Heckscher-Ohlin theory predicts that countries will specialize in the production of those traded goods that make more intensive use of the non-traded factor of which they have relative abundance. It also predicts that the benefits of trade will accrue to the comparatively more abundant factor; in other words, that the rental price of the comparatively more abundant factor will rise relative to that of the less abundant one.

What are these, all-important, non-traded factors? In traditional classroom accounts, they are capital and labour. Countries with a relative abundance of capital (developed countries, the so-called North) will thus export capital-intensive products. Countries with a relative abundance of labour (developing countries, the so-called South) will export labour-intensive products. Since, within each country, an increase in trade raises the price of the abundant factor relative to that of the scarce one, an implication of this vision of the world is that globalisation will make workers worseoff (relative to capitalists) in the North, better-off in the South. This, incidentally, justifies the alarm of trade unions in the North, but not the opposition of so many paladins of the underprivileged in the South.

\footnotetext{
${ }^{10}$ In Becker's terminology, public expenditure thus triggers a substitution of quality for quantity (of children).
} 


\subsection{Heckscher-Ohlin reconsidered}

This vision of the world has somewhat changed over the last couple of decades. Partly, this is a reflection of a general re-thinking of the development process. While early growth theory equated economic growth with the accumulation of physical capital (buildings and machinery) per head of population, modern theory does in fact attach much greater importance to the accumulation of human capital. ${ }^{11}$ Partly, however, the change of emphasis comes also from a recognition that physical capital is anything but immobile. Machinery can be moved around, and buildings can be taken down and rebuilt elsewhere. Since the financial capital (equity or debt instruments) needed to pay for plants and machinery is highly mobile, physical capital is then mobile too.

Human capital, by contrast, is embodied in skilled workers. These are more mobile than their unskilled brethren, but they, too, have their international mobility restricted by immigration rules and personal ties. As a broad generalization, one might then say that the fixed factors determining the comparative advantages of different countries are predominantly their different skill endowments. Of course, in the same way as capital endowments can be modified by investment, so skill endowments can be modified by education, but education takes much longer than the purchase of a new machine, or the construction of a plant, and workers are by-and-large more durable than physical capital. Starting from these premises, Adrian Wood has reformulated the theory of comparative advantage in terms of skill endowments: trading countries make and export the goods that make greater use of their comparatively more abundant skill level. Within each trading country, the benefit of increased world trade will then accrue to members of the relatively larger skill group (Wood, 1994). In other words, the wage rate of the comparatively larger group will rise relative to those of the others. Without special assumptions, however, the theory does not tell us whether the wage rates of the comparatively smaller groups will fall in absolute terms. As we will see, this is of some relevance.

For our purposes, the relevant skill categorization is into workers with less than completed primary education, workers with completed primary education, and workers with secondary or higher education. In developed countries, the proportion of

\footnotetext{
${ }^{11}$ Growth theorists have always been aware that both kinds of capital matter. If a simplification was required for analytical tractability, however, the variable left out used to be human capital. Starting with Becker, Murphy and Tamura (1990), the omitted variable now tends to be physical capital;.
} 
workers with less than completed primary education is negligible, and there are comparatively many workers with secondary or higher education. In those countries, globalization can thus be expected to raise the wage differential between more and less educated workers. In developing countries, by contrast, the proportion of workers with secondary or higher education is generally very small. ${ }^{12}$ In some of these countries, the comparatively larger group is that of workers who have not even completed primary education. ${ }^{13}$ There, globalization will raise the skill premium as in developed countries. In other developing countries, however, the comparatively larger group is that of workers with completed primary education. ${ }^{14}$ Here, globalization will reduce the skill premium.

\section{Table 1}

Descriptive Statistics for the Variables Employed in the Regressions

\begin{tabular}{lrrrr}
\hline Variable & Mean & Std. Dev. & Min & Max \\
\hline Child Labour & & & & \\
Trade & 18.567 & 16.180 & 0 & 70.89 \\
Open & 32.200 & 48.685 & 0 & 570.87 \\
Gdp & 0.426 & 0.495 & 0 & 1 \\
Health Expenditure & 3361.12 & 3594.67 & 343.7 & 24200 \\
100-Enrollment rate & 2.409 & 1.437 & 0.0001 & 7.76 \\
Primary & 22.257 & 22.289 & 0.100 & 85.5 \\
Secondary & 0.179 & 0.153 & 0.009 & 0.918 \\
\hline
\end{tabular}

Where there is a comparative abundance of workers with completed primary education, globalization may thus be expected to raise the wage rate of this group relative to that of less educated workers. As we saw in the last section, that will reduce child labour, and the effect will be larger if the wage rates of educated workers increase in absolute, as well as relative terms. A micro-econometric analysis of panel data for Vietnam ${ }^{15}$, a country with a comparative abundance of educated workers, finds a negative effect of international integration on child labour. By contrast, where there is a comparative abundance of workers who have not even completed primary education, child labour may rise or fall. It will definitely rise if the wage rates of the educated workers fall in absolute, as well as in relative terms.

\footnotetext{
${ }^{12}$ Less than 11 percent, on average, over the 1980-98 period; but it can go as low as 0.1 , or as high as 59 percent (see Table 1).

${ }^{13}$ The average of all developing countries for the $1980-98$ period is nearly 70 percent (see Table 1 ).

${ }^{14}$ The average is 18 percent, but the largest share, 92 percent, is a hundred times the smallest (see Table 1).
} 


\subsection{Intra-industry trade}

Globalization does not just mean more trade. It means also more trade in intermediate goods. By facilitating the coordination of dispersed production activities, falling transport costs and advances in information technology in fact favour the segmentation of production processes, and the location of different segments of the same process in different countries. The growing literature on this new aspect of international trade ${ }^{16}$ emphasizes the effects of market size on the international division of labour.

Gilles Duranton adds an extra dimension to this new trade theory by pointing out that, since the output of different segments of the same production process must be ultimately combined into a final good, the extent to which these different segments can be carried out in different countries is limited by the ability of different work forces to produce intermediate goods that will prove mutually compatible. As this means, in large measure, ability to deliver goods in time, and of the right quality, satisfying the compatibility requirement is clearly facilitated by the existence of work forces with similar characteristics. That is consistent with the observation that intraindustry trade has so far occurred mainly among countries at the same stage of development.

This argument points to a trade-off between comparative advantage, which privileges trade with unequals, and compatibility, which favours trade with equals. Tension between these two considerations may lead to complex dynamics, with a phase in which international trade is driven primarily by differences in relative factor endowments, and one in which work forces with similar characteristics form integrated production systems - coalitions of individuals, better-off trading with one another than with the world at large - that will uncouple from the rest of the world economy (Duranton, 1998). Instead of increasing wage inequalities within countries, international trade could thus end up increasing inequalities between countries (Krugman and Venables, 1995).

Acceptance into these clubs of countries, the members of which speak only to one another, is thus associated with the availability of educated workers in sufficient numbers. The countries more likely to be left out are the same ones where, according to Heckscher-Ohlin theory, exposure to international trade is most likely to reduce the

\footnotetext{
${ }^{15}$ The Vietnam Living Standards Survey, complemented by a survey of community-level prices.

${ }^{16}$ For a survey, see Ottaviano and Puga (1997).
} 
incentive for parents to educate their children. According to "old" trade theory, the danger for these countries is to become more backward through trade. According to "new" trade theory, the danger is that these countries will be excluded from economic integration with the more developed ones. Either way, children will suffer.

\section{Cross-country evidence}

Combined with household economics, trade theory thus tells us that exposure to international trade may or may not increase child labour. As we have seen, a necessary condition for this to be the case is that the country opening itself to international competition should have a comparatively large share of educated workers. Household economics on its own further tells us that policies aimed at lowering mortality are likely to reduce also child labour.

To test these propositions on the cross-country data mentioned in the Introduction, we regressed child labour on trade openness, real per-capita income, health policy, and skill composition. Child labour is alternatively measured by the 1014 labour participation rate, or by the primary school non-attendance rate. Trade openness is alternatively represented by the trade ratio (exports plus imports, divided by GDP) or by a dummy taking value one if the country is open according to the Sachs-Warner definition, zero otherwise. Real per-capita income is measured as GDP in constant PPP units per head of population. Health policy is represented by the share of public health expenditure in GDP. Skill composition is represented by the share of the workforce aged 25 or over which completed only primary education, and by that which attained secondary or higher education (the reference group is that without completed primary education). Descriptive statistics are reported in Table 1.

Skill composition is a stock concept, reflecting the cumulated effects of past educational policies. In view of the fact that current educational policies affect the incentive to send children to school, it would have been desirable to control for these policies too. Since child labour is a close correlate of school attendance, ${ }^{17}$ however, there is no way we could do that with our data. It would have also been desirable to control for differences in income distribution as a way of capturing the proportion of households subject to a binding liquidity constraint, but the information is not

\footnotetext{
${ }^{17}$ Where child labour is measured by the primary non-attendance rate, the correlation coefficient is -1 .
} 
comparable across countries and dates of observation. To the extent that public health expenditure and the share of educated workers in the total workforce are symptoms of government activism, however, these variables may be thought to act as proxies for income distribution.

Table 2a reports fixed-effect ${ }^{18}$ OLS estimates of the effects of trade on our two measures of child labour. If skill composition is not controlled for, trade raises the 1014 labour participation rate, but has no significant effect on the primary school nonattendance rate. If skill composition is controlled for, trade has no significant effect on either measure of child labour. The picture is somewhat more favourable to globalisation when trade is replaced by a dummy taking value 1 if the country is open in the Sachs-Warner sense, 0 otherwise. (Table $2 b$ ). Openness then reduces child labour, no matter how measured, even if we do not control for skill composition. ${ }^{19}$ Income, and public health expenditure, reduce both measures of child labour.

The effects of skill composition have the expected sign. The proportion of workers with completed primary education has a negative effect on child labour, and so does the share of workers with secondary or higher education (but takes significance away from the share of workers with completed primary education).

These findings are consistent with the theoretical considerations of the last section. What the data tell us in essence is that, other things being equal, international competition reduces or, at worst, has no significant effect on child labour. Interestingly, the more optimistic scenario is associated with the more stringent definition of trade openness, the one that takes into account the conditions under which trade takes place, rather than the actual volume of trade. Since the beneficial effects of international exposure come through relative price changes, it is in fact not irrelevant whether internal prices are subject to government control or free to adjust to international prices, and whether or not foreign trade is distorted by quotas and state monopoly.

\footnotetext{
${ }^{18}$ To account for unobserved heterogeneity

19 This is consistent with already mentioned longitudinal evidence from Vietnam; see Edmonds and Pavcnik (2001).
} 
Table 2a Estimates using the trade ratio as a measure of openness

\begin{tabular}{|l|c|c|c|}
\hline \multicolumn{5}{|l|}{ Dependent Variable Child Labour } \\
\hline Trade & $\begin{array}{c}0.065 \\
(2.34)^{*}\end{array}$ & $\begin{array}{c}0.05 \\
(1.65)\end{array}$ & $\begin{array}{c}0.031 \\
(1.1)\end{array}$ \\
\hline Gdp & -0.003 & -0.002 & -0.001 \\
& $(8.57)^{\star *}$ & $(4.71)^{* *}$ & $(2.89)^{\star *}$ \\
\hline Health & -3.202 & -2.036 & -2.136 \\
expend. & $(5.05)^{* *}$ & $(2.60)^{*}$ & $(2.92)^{* *}$ \\
\hline Primary & & -17.775 & -8.004 \\
& & $(2.57)^{*}$ & -1.18 \\
\hline Secondary & & & -43.291 \\
& & & $(4.75)^{* *}$ \\
\hline Constant & 31.441 & 28.581 & 29.735 \\
& $(17.67)^{\star *}$ & $(13.78)^{\star *}$ & $(15.28)^{* *}$ \\
\hline & & & 147 \\
\hline Obs. & 211 & 147 & 0.49 \\
\hline R-squared & 0.41 & 0.41 & \\
\hline Absolute value & & & \\
\hline
\end{tabular}

\begin{tabular}{|l|c|c|c|}
\hline \multicolumn{5}{|l|}{ Dependent Variable 100-Enrollment rate } \\
\hline Trade & 0.063 & 0.037 & 0.02 \\
& $(1.37)$ & $(0.78)$ & $(0.42)$ \\
\hline \multirow{2}{*}{ Gdp } & -0.003 & -0.001 & -0.001 \\
& $(5.05)^{\star *}$ & $(2.01)^{*}$ & $(0.86)$ \\
\hline Health & -3.882 & -1 & -1.214 \\
expend. & $(2.95)^{\star *}$ & -0.74 & $(0.91)$ \\
\hline Primary & & -42.77 & -34.788 \\
& & $(3.83)^{\star *}$ & $(3.00)^{\star *}$ \\
\hline \multirow{2}{*}{ Secondary } & & & -37.173 \\
& & & $(2.09)^{*}$ \\
\hline Constant & 36.286 & 30.95 & 31.591 \\
& $(10.68)^{\star *}$ & $(8.89)^{\star *}$ & $(9.19)^{* *}$ \\
\hline & & & \\
\hline Obs. & 142 & 102 & 102 \\
\hline R-squared & 0.26 & 0.33 & 0.36 \\
\hline
\end{tabular}

Absolute value of t-statistics in parentheses

* significant at $5 \%$; ${ }^{* *}$ significant at $1 \%$

The coefficients of the skill composition variables measure the effects of increasing the proportion of the total workforce that ha achieved a certain educational level (primary only, secondary or higher), holding all the other variables (openness included) constant at their mean values. Given that openness is quite high on average (43.35 percent of the sample is "open" by the Sachs-Warner definition, trade is on average 32.25 percent of GDP), these findings are compatible with the proposition that (a) trade increases the skill premium in countries with a comparative abundance of educated workers, and (b) only countries with a sufficiently educated workforce are able to integrate in the emerging global economy. However, if we try to interact openness with skill composition, all variables other than the interaction terms lose significance. Clearly, therefore, our data do not allow us to disentangle the effect of skill composition per se, from the combined effect of skill composition and trade openness. 
Table 2b Estimates using Sachs-Warner measure of openness

\begin{tabular}{|c|c|c|c|}
\hline \multicolumn{4}{|c|}{ Dependent Variable Child Labour } \\
\hline Open & $\begin{array}{l}-10.243 \\
(5.47)^{\star *}\end{array}$ & $\begin{array}{c}-7.664 \\
(3.74)^{\star *}\end{array}$ & $\begin{array}{c}-6.999 \\
(3.64)^{\star *}\end{array}$ \\
\hline Gdp & $\begin{array}{c}-0.002 \\
(7.39)^{\star *}\end{array}$ & $\begin{array}{c}-0.001 \\
(5.22)^{\star *}\end{array}$ & $\begin{array}{c}-0.001 \\
(2.89)^{\star *}\end{array}$ \\
\hline $\begin{array}{l}\text { Health } \\
\text { expend }\end{array}$ & $\begin{array}{c}-2.881 \\
(4.03)^{\star *}\end{array}$ & $\begin{array}{c}-2.198 \\
(2.80)^{\star *}\end{array}$ & $\begin{array}{c}-2.474 \\
(3.35)^{\star *}\end{array}$ \\
\hline Primary & & $\begin{array}{c}-13.049 \\
(1.87)\end{array}$ & $\begin{array}{c}-3.086 \\
(0.45)\end{array}$ \\
\hline Secondary & & & $\begin{array}{l}-43.505 \\
(4.35)^{\star \star}\end{array}$ \\
\hline Constant & $\begin{array}{c}35.955 \\
(18.36)^{\star \star}\end{array}$ & $\begin{array}{c}32.165 \\
(14.37)^{\star \star}\end{array}$ & $\begin{array}{c}33.307 \\
(15.75)^{\star *}\end{array}$ \\
\hline Obs. & 166 & 136 & 136 \\
\hline R-squared & 0.49 & 0.44 & 0.51 \\
\hline
\end{tabular}

\begin{tabular}{|l|c|c|c|}
\hline \multicolumn{5}{|c|}{ Dependent Variable 100 -Enrollment rate } \\
\hline Open & -7.128 & -2.077 & -1.293 \\
& $(1.86)$ & $(0.58)$ & $(0.37)$ \\
\hline Gdp & -0.002 & -0.001 & -0.0003 \\
& $(4.28)^{* *}$ & $(2.04)^{*}$ & $(0.63)$ \\
\hline Health & -4.436 & -1.315 & -1.389 \\
expend & $(2.94)^{* *}$ & $(0.95)$ & $(1.02)$ \\
\hline Primary & & -43.612 & -35.673 \\
& & $(3.73)^{* *}$ & $(2.96)^{\star *}$ \\
\hline Secondary & & & -40.63 \\
& & & $(2.16)^{*}$ \\
\hline Constant & 41.921 & 32.225 & 32.64 \\
& $(10.58)^{* *}$ & $(8.46)^{* *}$ & $(8.74)^{* *}$ \\
\hline & & & 94 \\
\hline Obs. & 116 & 94 & 0.35 \\
\hline R-squared & 0.3 & 0.31 & \\
\hline
\end{tabular}

Absolute value of t-statistics in parentheses

* significant at $5 \%$; ${ }^{* *}$ significant at $1 \%$

The share of public health expenditure in GDP significantly reduces the 10-14 labour participation rate whether or not we control for skill composition, but its effect on the primary school non-attendance rate is insignificant if skill composition is controlled for. This finding is coherent with the theoretical argument and microeconometric evidence mentioned in section 3, that health and educational outcomes are jointly determined by health and education policies. But, again, we are unable to capture these complex interactions with our cross-country data.

\section{Conclusion}

There is no empirical evidence that exposure to international trade, and economic integration across national borders, raise the incidence of child labour. If anything, the evidence points the other way. The theoretical explanation runs as follows. Parental decisions whether a child should work or go to school depend on the costs and benefits of education. Due to capital market imperfections, however, educational investments may be limited by household liquidity constraints.

In a country that starts out with a largely uneducated workforce, globalisation raises the wage rates of uneducated, relative to educated workers. That reduces the incentive to educate a child, and raises the incentive to make the child work at the earliest opportunity. On the other hand, if the wage rate of uneducated workers rises 
in absolute as well as relative terms, this will have a positive income-effect on the demand for education The net effects of globalisation are thus ambiguous.

Where the countries at the bottom of the pile are concerned, there is also another problem. According to a variant of new trade theory, a country that starts out with a largely uneducated workforce risks being excluded from trade in intermediate goods with the more developed countries as the latter form exclusive clubs. Globalisation could thus further impoverish countries with particularly unfavourable initial conditions. For all these reasons, child labour is likely to rise where the share of educated workers is very low.

By contrast, in a country that starts out with a comparatively large share of educated workers, globalisation will raise the wage rates of these workers relative to those of uneducated ones. Very few developing countries have a sizeable proportion of the workforce educated to secondary or higher level, but some have a comparative abundance of workers with completed primary education. For this elite of the developing world, exposure to trade raises the incentive for parents to send their children to school. However, if the wage rates of uneducated workers fall in absolute terms, as well as relative to those of educated workers, there will be a negative income-effect on the demand for education by households where the parents are themselves uneducated, and this effect will be stronger in the presence of a the liquidity constraint. The net effects of globalisation are thus ambiguous for this category of developing countries too, but child labour is more likely to fall.

The role of national policy in the face of increasing international integration is different for the two categories of countries. For those with a relative abundance of uneducated workers, the primary aim is to restore (or create) the incentive for parents to send their children to school. In countries with a relative abundance of educated workers, by contrast, the problem is rather that of relaxing the liquidity constraint for households where the parents are illiterate.

For all its limitations, ${ }^{20}$ the available cross-country evidence appears to bear out these theoretical considerations. Controlling for GDP, skill composition of the adult workforce, and weight of public health expenditure in GDP, trade openness is found to have a negative effect on child labour (the ratio of trade to GDP has no significant effect). The existence of an educated workforce (not the number of

\footnotetext{
${ }^{20}$ But single-country evidence based on micro-data, to which we have referred in the body of the paper, points in the same direction.
} 
children currently going to school) is associated with a low incidence of child labour. The share of public health expenditure in GDP tends to reduce child labour.

Concern that trade exposure per se could be a cause a rise in child labour does not appear to be well founded, except insofar as countries with a largely uneducated workforce could be left out of the globalisation process, and become poorer as a result. There, however, the problem is not so much globalisation, as the ability to take part in it.

\section{References}

Balland, J.M. and A. Robinson (2000), "Is Child Labor Inefficient?”, Journal of Political Economy 108, 663-679

Basu, K. and P.H. Van (1998), "The Economics of Child Labor", American Economic Review 88, 412-427

Becker, G.S. (1981), A Treatise on the Family, Harvard University Press, Cambridge, Mass.

Becker, G.S., Murphy, K.M. and R.F. Tamura (1990), "Human Capital, Fertility and Economic Growth", Journal of Political Economy 98, S12-S37

Cigno, A. (1991), Economics of the Family. Clarendon Press and Oxford University Press, Oxford and New York

Cigno, A. (1993), "Intergenerational Transfers without Altruism: Family, Market and State", European Journal of Political Economy 7, 505-518

Cigno, A. (1998), "Fertility Decisions When Infant Survival Is Endogenous", Journal of Population Economics 11, 21-28

Cigno, A. (2001), "Comparative Advantage, Observability, and the Optimal Tax Treatment of Families with Children", International Tax and Public Finance 8, 455470

Cigno, A. and F.C. Rosati (2002), "Child Labour, Education and Nutrition in Rural India”, Pacific Economic Review 7, 1-19.

Cigno, A., Rosati, F.C. and Z. Tzannatos (2002), Handbook of Child Labor, The World Bank, Washington D.C.

Duranton, G. (1998), Globalisation, Productive Systems and Inequalities, Centre for Economic Performance, London

Edmonds, E. and N. Pavcnik (2001), Does Globalisation Increase Child Work?, Dartmouth College and NBER, mimeo 
Grootaert, C. and R. Kanbur (1995), "Child Labor: An Economic Perspective", International Labor Review 134, 187-203

Krugman, P. (1995), “Growing World Trade: Causes and Consequences”, Brookings Papers on Economic Activity 1, 327-377

Krugman, P. and A. Venables (1995), "Globalisation and the Inequality of Nations", Quarterly Journal of Economics 110, 857-880

Ottaviano, G. and D. Puga (1997), Agglomeration in the Global Economy: A Survey of the New Economic Geography, CEPR W.P. N 1699

Ray, R. (2000), "Analysis of Child Labour in Peru and Pakistan: a Comparative Study", Journal of Population Economics 13, 3-20

Rosati, F.C. (1996), "Social Security in a Non-Altruistic Model with Uncertainty and Endogenous Fertility", Journal of Public Economics 60, 283-294

Rosati, F.C. (1999), "Child Work", World Bank D.P.

Rosati, F.C. (2000), Morocco: Reducing Child Labor by Increasing School Availability. World Bank WP

Rosenzweig. M.R. (1995), "Why Are there Returns to Schooling?”, American Economic Review Papers and Proceedings 85, 153-158

Rosenzweig. M.R. and K.J. Wolpin (1982), "Governmental Interventions and Household Behavior in a Developing Country", Journal of Development Economics $10,209-225$

Sachs, J.D. and A. Warner (1995), "Economic Reform and the Process of Global Integration", Brookings Papers on Economic Activity 1

Wood, A. (1994), North-South Trade, Employment and Inequality, Clarendon Press, Oxford

Wood, A. (1998), "Globalisation and the Rise in Labour Market Inequalities", Economic Journal 108, 1463-1482 


\section{IZA Discussion Papers}

No.

Author(s)

455

J. T. Addison

C. R. Belfield

456

T. M. Andersen

457

M. Lindeboom

M. Kerkhofs

458

M. Galeotti

L. J. Maccini

F. Schiantarelli

459

M. Biewen

460

B. R. Chiswick

Y. Liang Lee

P. W. Miller

461

462

463

J. Ermisch

M. Francesconi

J. E. Askildsen

E. Bratberg

$\varnothing$. A. Nilsen
A. Venturini

C. Villosio

J. Wagner

R. Lalive

J. C. van Ours

J. Zweimüller
Title

Area

Date

Unions and Establishment Performance:

3

03/02

Evidence from the British Workplace Industrial/

Employee Relations Surveys

International Integration, Risk and the Welfare

State

Health and Work of the Elderly: Subjective

Health Measures, Reporting Errors and the

Endogenous Relationship between Health and Work

Inventories, Employment and Hours

5

03/02

The Covariance Structure of East and West

German Incomes and its Implications for the

Persistence of Poverty and Inequality

Family Matter: The Role of the Family in

2

03/02

Immigrants' Destination Language Acquisition

Welfare and Labor Earnings:

3

03/02

An Evaluation of the Financial Gains to Work

The Determinants of the Geographic

2

$03 / 02$

Concentration among Immigrants: Application to

Australia

Labor Supply Dynamics, Unemployment and

Human Capital Investments

The Hold-Down Problem and the Boundaries of the Firm: Lessons from a Hidden Action Model with Endogenous Outside Option

Intergenerational Social Mobility and Assortative Mating in Britain

Unemployment, Labour Force Composition and 1 Sickness Absence: A Panel Data Study

$04 / 02$

Are Immigrants Competing with Natives in the

04/02 Italian Labour Market? The Employment Effect

The Impact of Risk Aversion, Role Models, and $04 / 02$ the Regional Milieu on the Transition from Unemployment to Self-Employment: Empirical Evidence for Germany

The Effect of Benefit Sanctions on the Duration of Unemployment

L. Guarcello 